\title{
Uzaktan Eğitim Sürecinde Öğretmen ile Öğrenci-Veli İletişimi: Sosyal Bilgiler Öğretmenlerinin Deneyimleri
}

\author{
Arcan AYDEMIR ${ }^{1}$
}

Öz

Covid-19 salgını sürecinde gerçekleştirilen uzaktan eğitim faaliyetlerinde sosyal bilgiler öğretmenlerinin öğrenci ve velilerle iletişim kurma deneyimlerine odaklanan çalışma ile uzaktan eğitimde iletişimin önemi, kullanılan araçlar, sorun ve önerilerin ayrıntılı bir şekilde incelenmesi amaçlanmıştır. Araştırmada fenomenoloji yaklaşımı kullanılmıştır. Araştırmanın çalışma grubunu Türkiye'de çeşitli okullarda çalışan 30 sosyal bilgiler öğretmeni oluşturmaktadır. Araştırma kapsamında elde edilen verilerin toplanmasında "Görüşme Formu" kullanılmıştır. Verilerin çözümlenmesinde içerik analizi tekniği kullanılmıştır. Araştırma sonucunda çalışma grubunda yer alan sosyal bilgiler öğretmenlerinin uzaktan eğitimde amaca ulaşmak, süreci etkin bir şekilde sürdürmek için iletişimin önemli olduğu görüşüne sahip olduklarına, uzaktan eğitim sürecinde ders ve ödev verme, motive etme gibi gerekçelerle iletişim kurduklarına, hem öğrenci hem de velileriyle iletişim kurarken telefon, mesajlaşma ve arama uygulamaları gibi araçlar kullandıklarına ulaşılmıştır. Buna ek olarak sosyal bilgiler öğretmen öğretmenleri bu süreçte hem öğrenci hem de velilerle bir takım sorunlar yaşadıklarını ifade etmişlerdir. Öğrencilerle gerçekleştirilen iletişim sürecinde veli, olanak eksikliği, öğrencinin kendisi ve iletişim sürecindeki eksikliklerden kaynaklı sorunlar yaşanmıştır. Çalışma grubunda yer alan sosyal bilgiler öğretmenlerinin velilerle gerçekleştirdikleri iletişim süreçlerinde ise daha çok velilerin öğrencileri motive etmemesi, iş yoğunluğu gibi veli kaynaklı bir takım sorunlar yaşadıkları sonucuna ulaşılmıştır. Son olarak sosyal bilgiler öğretmenleri uzaktan eğitimde iletişimde alt yapı sorunlarının giderilmesi, iletişimin planlı ve düzenli bir şekilde yapılması gerektiği şeklinde önerileri ileri sürmüşlerdir.

Anabtar Kelimeler: Uzaktan eğitim, İletişim, Uzaktan eğitimde iletişim, Sosyal bilgiler

\section{Teacher-Student-Parent Communication in the Distance Education Process: Social Studies Teachers' Experiences}

\section{Abstract}

This study aims to investigate the importance of communication in distance education, tools used, problems, and recommendations in detail with a central focus on the experiences of social studies teachers in communicating with students and parents in the distance education activities carried out during the Covid-19 epidemic process. This research used a phenomenological research design. The sample included 30 social studies teachers working in various schools in Turkey. The data were collected using an interview form and content analysis. The data were examined thoroughly and sorted into categories and codes. According to the results of the study, the sampled social studies teachers held the view that communication is important in achieving the goal in the distance education and sustaining the process effectively and efficiently, while they were communicating with both students and parents through mobile phones, messages, and phone calls for reasons such as teaching, assigning homework, and providing motivation. The social studies teachers also stated that they had a number of problems with both students and parents throughout this process. During teachers' communication with students, there were problems arising from parents, the lack of facilities, students themselves, and the deficiencies in the communication process. During the communication with parents, the social studies teachers experienced parent-related problems such as parents' workload and the lack of parental motivation for students. Finally, the social studies teachers suggested that infrastructure problems in distance education should be solved, planned and communication should be established.

Key Words: Distance education, Communication, Communication in distance education, Social studies

\section{Atıf İçin / Please Cite As:}

Aydemir, A. (2021). Uzaktan eğitim sürecinde öğretmen ile öğrenci-veli iletişimi: Sosyal bilgiler öğretmenlerinin deneyimleri. Manas Sosyal Araştırmalar Dergisi, 10(2), 813-827.

Geliş Tarihi / Received Date: 10.11.2020

Kabul Tarihi / Accepted Date: 06.03.2021

\footnotetext{
1 Arş. Gör. Dr. - Artvin Çoruh Üniversitesi, Eğitim Fakültesi, Türkçe ve Sosyal Bilimler Eğitimi Bölümü, arcan.aydemir@hotmail.com

iD ORCID: 0000-0001-8110-954X
} 


\section{Giriş}

Dünyada meydana gelen ve toplumu yakından etkileyen olaylar eğitim-öğretim faaliyetlerini de etkilemektedir. Küresel anlamda dünyayı etkileyen son dönemlerdeki en önemli olaylardan biri de Covid19 salgını olmuştur. Dünyayı etkileyen salgın eğitim-öğretim faaliyetlerinde de bir takım değişikliklere sebep olmuş, uzaktan eğitim, eğitim-öğretimin önemli bir parçası haline gelmiştir.

2020 yılında bütün dünyayı etkisi altına alan Covid-19 salgını sonucunda birçok ülke acil bir şekilde açık ve uzaktan öğrenmeye geçmiştir. Bu bağlamda Türkiye'de de birçok eğitim kademesinde eş zamanlı veya eş zamansız uzaktan eğitim faaliyetlerine geçilmeye başlanmıştır. Milli Eğitim Bakanlı̆̆ı EBA (Ĕ̈itim Bilişim ağı) ve EBA TV aracilı̆̆ıla öğrencilere ulaşarak, eğitim-öğretim süreçlerinin devam etmesini sağlamıştır (Özcan, 2020, s. 203). Oluşabilecek beklenmedik acil durumlarda ise eğitim-öğretim faaliyetlerinin etkin bir şekilde yürütülmesinde süreç deneyimlerine odaklanılarak sorunların belirlenmesi ve giderilmesi önemlidir.

İnsanın doğumuyla birlikte başlayan ve hızlı bir şekilde gelişim gösteren eğitim, disiplinler arası bir kavramdır (Güneş, 2015, s. 2). Dinamik bir olgu olan eğitim, bir bilim ve yaşam alanıdır (Yılmaz ve Sarpkaya, 2019, s. 3). Eğitim faaliyetleri zaman içinde koşullara bağlı olarak değişikliklere uğrayabilir. Eğitim-öğretimin gerçekleştirilmesinde benimsenen süreçlerden biri de uzaktan eğitimdir. Uzaktan eğitimin gelişimi ve yaygınlaşmasında 80'li yıllardan beri bilgisayar ve internetin kullanılması etkili olmuştur. Televizyon, basılı materyaller, mektup, radyo gibi araçların yerini bilişim teknolojileri almaya başlamıştır (Berigel ve Çetin, 2020, s. 128). Gelişen teknolojiler ise uzaktan eğitim süreçlerinde kullanılan araçgereçlerin hem niteliğinde hem de niceliğinde bir takım değişikliklere sebep olabilir.

\section{Uzaktan Eğitim}

Kavramsal olarak ortaya çıkışı 1700 ’ü yıllara dayanan (Ulu Kalın ve Baydar, 2020, s. 263) uzaktan eğitim 1960-1980'li yıllarda televizyonun insan hayatına girmesi ve yaygınlaşmasıyla kitle iletişim araçlarına taşınmıştır. Bilgi ve iletişim teknolojilerindeki gelişime bağlı olarak yönünü 1990'lı yıllarda ise internet ve bilgisayara döndürmüştür (Devran ve Elitaş, 2017, s. 218). Türkiye'de ise uzaktan eğitim ile ilgili tartışmalar 1927, uzaktan eğitim uygulamalarının başlaması 1982 yıllarına dayanmaktadır (Usun, 2004, s. 4).

Özellikle teknolojide meydana gelen dönüşümler, eğitim kapsamında da birtakım değişimlere sebep olmuştur. Bu durum ise okullara olan ihtiyacında sorgulanmasına zemin hazırlamıştır. Önceleri uzaktan eğitim ortamları okullarda öğrenilemeyen bilgilerin öğrenildiği ortamlar olarak ele alınırken, günümüzde uzaktan eğitim ortamlanı okulun alternatifi olarak ele alınmaya başlamıştır (Yavuz, 2018, s. 16). Uzaktan eğitimin "her zaman her yerde" anlayışa sahip olması, uzaktan eğitimi birçok insan için çekici hale getirmiştir (Redfern ve Naughton, 2002, s.212). İnsanlara bilgiyi geliştirme ve güncelleme şansı sunan uzaktan eğitim, öğrenmenin bireyselliğine ve esnekliğine vurgu yapmaktadır (Schlosser ve Anderson, 1994, s. 4).

Uzaktan eğitimi bir kuruma tanıtmak veya uzaktan eğitim odaklı bir kurum kurmak bazı değişikliklerin yapılmasını gerektirir. Bu bağlamda öğretim ve kaynak kullanımında önemli değişiklikler yapmak şarttır. Bu süreçler ise özellikle politika yapıcılar tarafindan dikkatli bir şekilde değerlendirilmelidir (Moore ve Kearsley, 2012, s. 8) Bu yüzden uzaktan eğitim faaliyetleri boyunca geri bildirimler ve süreci iyileştirmeye yönelik önlemler almak gerekir.

Uzaktan eğitimde geleneksel olarak yürütülen eğitim ortamlanındaki roller değişikliğe uğrar. Bu süreçte hem öğreten hem de öğrenen yeni roller üstlenmektedir (Berigel ve Çetin, 2020, s.127). Üstlenilen bu rollerin eğitim-öğretim faaliyetlerine olumlu bir şekilde katk1 sağlaması hedeflenmelidir. Uzaktan eğitimin eğitim-öğretim faaliyetlerine olumlu pek çok katkısı bulunmaktadır. Bu katkılar ise öğrencilerin değişik zamanlarda tekrar ve çalş̧ma firsatı sunması, geri bildirim olanağı, öğrenme faaliyetlerinin raporlanabilir olması, öğrenciye eşit düzeyde bilgi sunması şeklinde sıralanabilir (Elcil ve Sözen-Şahiner, 2014, s.24). Uzaktan eğitimin eğitim ve öğretim faaliyetlerine katk1 sunmasında ise öğrenci öğretmen iletişimi önemlidir.

\section{İletişim}

Toplumsal bir varlık olarak insan içinde yaşadığı toplumdaki diğer insanlarla etkileşim kurma ihtiyacına sahiptir. İnsan, kendini dünyaya hazırlayacak bilgileri edinmek ve başkalarını anlamak için küçük yaştan itibaren iletişim kurmaktadır. İnsanın biyolojik bir varlıktan toplumsal bir varlığa dönüşmesinde ise iletişim etkili olmuştur (Tuna, 2014, s. 4). 
İnsanlık tarihi kadar eski olan iletişim kavramı insanlığın var olmaya başladığı zamandan beri uygulanmaya başlamıştır. İnsanoğlunun iletişim kurmasında ise karşılaştı̆ı sorunları çözmeye çalş̧ma ve ortaklık içinde anlaşma zorunluluğudur. İletişim araçları veya süreçleri devirden devire farkllık gösterse de iletişim hayatın her döneminde olmuştur (Yılmazer, 2020, s. 13). İnsanların iletişim kurmadan hayatlarını sürdürmeleri ise imkansızdır (Güven, 2016, s. 1).

Günümüzde en önemli olgulardan biri olan iletişim, hem başkalarını etkilemek hem de başkalarından etkilenmeyi amaçlamaktadır. İnsan sosyal bir varlık olarak hayatını sürdürebilmesi için iletişime ihtiyacı vardır (Fidan, 2019, s. 1-2). İnsanın sahip olduğu iletişim gücü, kendisini ve çevresini tanımasına, toplumda yer alan diğer insanlarla uyumlu ilişkiler geliştirebilmesi için etkileşim oluşturmasına olanak tanıyan önemli bir beceridir (Yüksel, 2019, s. 4).

\section{Uzaktan Eğitimde İletişim}

Eğitim alanını etkileyen alanlardan biri de bilgi ve iletişim teknolojileridir. Bilgi ve iletişim teknolojileri ise bilgiyi araştırma, bilgiyi paylaşma ve bilgiyi öğrenme açısından önemli faydalar sağlamaktadır. Okullarda kullanilan kitap ve dergi gibi basilı materyallerin yerini bilgisayar, televizyon ve video gibi teknolojiler almaya başlamıştır. Bu değişim eğitimde basılı ürünlerin kullanılması anlayışını değiştirerek yerine mobil ögrenme, ekranik düşünme ve ekrana yazma-okuma gibi kavram ve becerilerin ortaya çıkmasına sebep olmuştur (Güneş, 2015, s. 3). Etkileşimli iletişim teknolojilerinde meydana gelen yenilikler ise hem ögrenciler ve öğretmenler arasında hem de öğrencilerin kendi aralarında uzaktan senkronize iletişim kurmalarını sağlamıştır (Guri-Rosenblit, 2005, s. 470).

Uzaktan öğrenme süreçlerine katılımın sağlanması için eğitmen tarafindan gerçekleştirilen iletişim seçeneklerini çeşitlendirilmesi gerekir. Özellikle eğitmen-öğrenen, öğrenci-öğrenci ve öğrenci-içerik etkileşimini sağlamak için bazı içerikler kullanılabilir. Şekil 1'de bu etkileşimleri sağlamak için kullanılabilecek içeriklere yer verilmiştir (Durdu, 2020, s. 233-234):
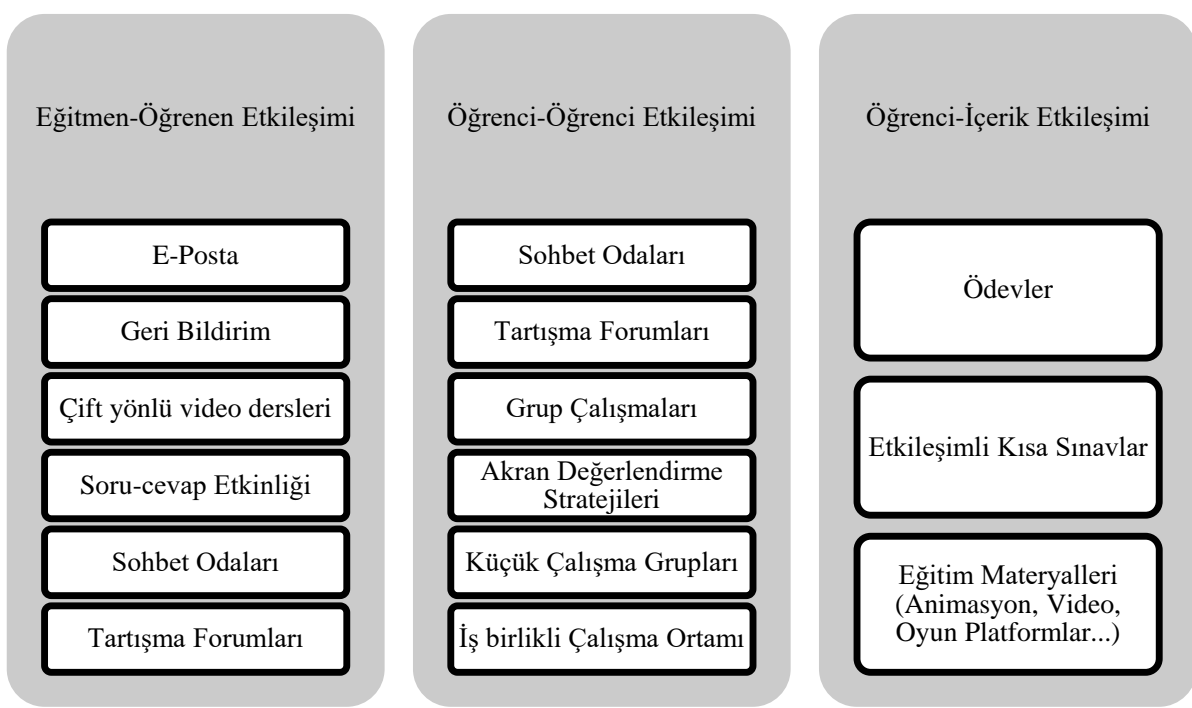

Şekil 1. Uz̧aktan Ögrrenme Ortaminda Etkileşim Sağlamada Kullanulabilecek İcerikler (Durdu, 2020, s. 233-234)

Uzaktan eğitim sürecinde eğitici veya öğreticiden kaynaklı, fiziksel uzaklıkla ilgili, kanal kaynakl, zaman baskısı gibi bir takım iletişim engelleri yaşanabilir (Elcil ve Sözen-Şahiner, 2014, s. 26). Bu durum ise uzaktan eğitim süreçlerinde başarısızlıklara sebep olabilir. Uzaktan eğitim sürecinin başarılı bir şekilde uygulanmasının önündeki engellere, öğretmenlerin süreç deneyimlerine, uzaktan eğitim ortamlarına ve uzaktan eğitim programlarına odaklanan çok sayıda çalışma bulguları literatüre önemli bilgiler sunmaktadır (Muilenburg ve Berge, 2001, s. 7).

Salgın sürecinde gerçekleştirilen uzaktan eğitim faaliyetlerinin amaca ulaşması için bir takım önlemler almak ve süreci etkin bir şekilde yürütmek gerekir. Bu durumda hem öğrenci hem de velilerle iletişim kurmak çok önemlidir. Literatür incelendiğinde Covid-19 salgını sürecinde öğretmen deneyimlerine odaklanan çalışmaların yapıldığ1 görülmektedir (Bakioğlu ve Çevik 2020; Bayburtlu, 2020; Canpolat ve Ylldırım, 2021; Hebebci, Bertiz ve Alan, 2020; Koçoğlu, Ulu Kalın, Tekdal ve Yiğen, 2020; Lindner, Clemons, Thoron ve Lindner, 2020; Sönmez, Yıldırım ve Çetinkaya, 2020). Bu çalışmada ise özellikle 
Covid-19 salgını sürecinde uzak eğitimde sosyal bilgiler öğretmenlerinin hem öğrencileriyle hem de velileriyle kurdukları iletişim deneyimlerine odaklanılmıştır. Bu bağlamda çalışmanın, sosyal bilgiler öğretmenlerinin Covid-19 salgınında gerçekleştirdikleri uzaktan eğitim sürecinde iletişim kurma deneyimlerini, iletişim amaçlı kullanılan araç-gereçleri, iletişim engellerini ve sürece yönelik önerilerini ortaya çıkarması açısından literatüre katkı sunacağı düşünülmektedir.

\section{Araştırmanın Amacı}

Araştırmanın temel amacı Covid-19 salg1nı sürecinde gerçekleştirilen uzaktan eğitim faaliyetlerinde sosyal bilgiler öğretmenlerinin öğrenci ve velileriyle kurduklar1 iletişim süreçlerine yönelik deneyimlerini incelemektir. İletişim süreçlerinin veli ve öğrenci boyutu ayr1 ayrı incelenmiştir. Bu temel amaç doğrultusunda aşağıdaki sorulara cevap aranmıştır:

- Sosyal bilgiler öğretmenleri için Covid-19 salgını sürecinde gerçekleştirilen uzak eğitim faaliyetlerinde iletişim önemli midir? Neden?

- Sosyal bilgiler öğretmenlerinin Covid-19 salgını sürecinde gerçekleştirdikleri uzaktan eğitim faaliyetlerinde en fazla iletişim kurdukları hedef kitle hangisidir?

- Sosyal bilgiler öğretmenleri Covid-19 salgını sürecinde gerçekleştirdikleri uzaktan eğitim faaliyetlerinde öğrenci ve velilerle iletişim kurarken hangi iletişim teknolojilerini kullanmışlardır?

- Sosyal bilgiler öğretmenlerinin Covid-19 salgını sürecinde gerçekleştirdikleri uzaktan eğitim faaliyetlerinde öğrenci ve velilerle iletişim kurma gerekçeleri nelerdir?

- Sosyal bilgiler öğretmenleri Covid-19 salg1nı sürecinde gerçekleştirdikleri uzaktan eğitim faaliyetlerinde öğrenci ve velilerle sorun yaşadılar mı? Sorun yaşayan sosyal bilgiler ögretmenlerinin yaşadıkları sorunlar nelerdir?

- Sosyal bilgiler öğretmenlerinin uzaktan eğitim faaliyetlerindeki iletişim süreçlerine yönelik önerileri nelerdir?

\section{Yöntem}

Bu bölümde araştırmanın modeline, çalışma grubuna, veri toplama aracına, verilerin toplanmasına ve verilerin analizine ilişkin bilgilere yer verilmiştir.

\section{Araştırmanın Modeli}

Araştırmada fenomenoloji (görüngübilim) yaklaşımı kullanılmıştır. Edmund Husserl'in felsefesine dayanan fenomenoloji, durumları, olayları, deneyimleri veya kavramları açıklamak veya incelemek için kullanılan bir yöntemdir (Sönmez ve Alacapınar, 2019, s. 92-93). Bu çalışmada ise uzaktan eğitim sürecinde sosyal bilgiler öğretmenlerinin öğrenci ve velileriyle kurdukları iletişim deneyimleri incelenmiştir.

\section{Çalışma Grubu}

Araştırmanın çalışma grubunu 2019-2020 ve 2020-2021 eğitim-öğretim yıllnda Türkiye'de çeşitli okullarda çalışan sosyal bilgiler öğretmenleri oluşturmaktadır. Çalışma grubu oluşturulurken amaçlı örnekleme yöntemi kullanılmıştır. Çalışma grubunu belirlerken aşağıdaki ölçütler dikkate alınmıştır:

- Çalışmaya gönüllü olarak katılıyor olmak,

- Sosyal bilgiler öğretmenliği yapıyor olmak,

- Salg1n sürecinde sosyal bilgiler dersi vermiş/veriyor olmak,

Araştırma kapsamında toplamda Türkiye genelinde 35 sosyal bilgiler öğretmenine ulaşılmış, 5 sosyal bilgiler öğretmeninin belirlenen kriterlere uygun olmadığı (Salgıın döneminde uzaktan eğitim yapmama, gönüllü olmama) gerekçesiyle çalışma grubuna dahil edilmemiştir. Araştırma kapsamındaki katılımcılara ilişkin bilgilere ise Tablo 1'de yer verilmiştir. 
Tablo 1. Calıs̆ma Grubunda Yer Alan Katıllmollara İlișkin Bilgiler

\begin{tabular}{llccc}
\hline & & Özellikler & Kişi Sayis1 & Yüzde \\
\hline \multirow{2}{*}{ Cinsiyet } & Kadın & 18 & 60 \\
& Erkek & 12 & 40 \\
\hline \multirow{2}{*}{ Kurum } & Ortaokul & İmam Hatip Ortaokulu & 26 & 86.7 \\
& 12 Ylldan Fazla & 4 & 13.3 \\
\hline \multirow{4}{*}{ Kidem } & 3Yıldan Az & 13 & 43.3 \\
& 3-6 Yil & 6-9 Yil & 5 & 16.7 \\
& 9-12 Yll & 3 & 10 & 26.7 \\
& 27-32 Yaş & 8 & 3.3 \\
\hline \multirow{4}{*}{ Yaş } & 34-40 Yaş & 1 & 33.3 \\
& 41-48 Yaş & 10 & 30 \\
& 50-55 Yaş & 9 & 26.7 \\
\hline
\end{tabular}

Araştırmanın çalışma grubunu 18 kadın 12 erkek olmak üzere toplam 30 sosyal bilgiler öğretmeni oluşturmaktadır. Katılımcıların çoğu ortaokulda ( $\mathrm{n}=26, \% 86.7)$ çalışmakta, 12 yıldan fazla kıdeme ( $\mathrm{n}=13$, $\% 43.3)$ sahip ve 27-32 yaş ( $\mathrm{n}=10, \% 33.3)$ aralığındadır.

\section{Veri Toplama Arac1}

Araştırma kapsamında elde edilen verilerin toplanmasında "Yarı Yapılandırılmış Görüşme Formu" kullanılmışır. Veri toplama aracı uygulanmadan önce araştırmanın içeriği, amaç ve alt amaçlarına ilişkin bilgiler alan eğitimcisi ve sosyal bilgiler öğretmenine aktarılmış ve araştırmada kullanılan veri toplama aracına yönelik görüşleri alınmışır. Dönütler doğrultusunda veri toplama aracına son hali verilmiştir. Veri toplama aracında 5 adet açı uçlu 5 adet de tek cevaplı soruya yer verilmiştir.

\section{Verilerin Toplanması}

Çalışmanın verileri Covid-19 salgını sürecinde toplandığından ve katılımcıların farklı şehirlerden seçilmesinden dolayı görüşme formunda yer alan sorular katılımcılara interaktif ortamda yazılı olarak sunulmuştur. Katılımcıların görüşleri ise yazılı olarak toplanmıştır.

\section{Verilerin Analizi}

Verilerin çözümlenmesinde içerik analizi kullanılmıştır. Bu bağlamda elde edilen veriler ayrıntılı bir şekilde incelenerek kategori ve kodlara ayrılmıştır. Buna ek olarak elde edilen bulguların yüzde ve frekans değerleri belirlenmiştir. Öğretmen görüsslerinin yüzdeleri ise toplam katılımcı sayısına göre hesaplanmıştır. Şekil $2^{`}$ de verilerin analizi aşamasında izlenen basamaklara yer verilmiştir.

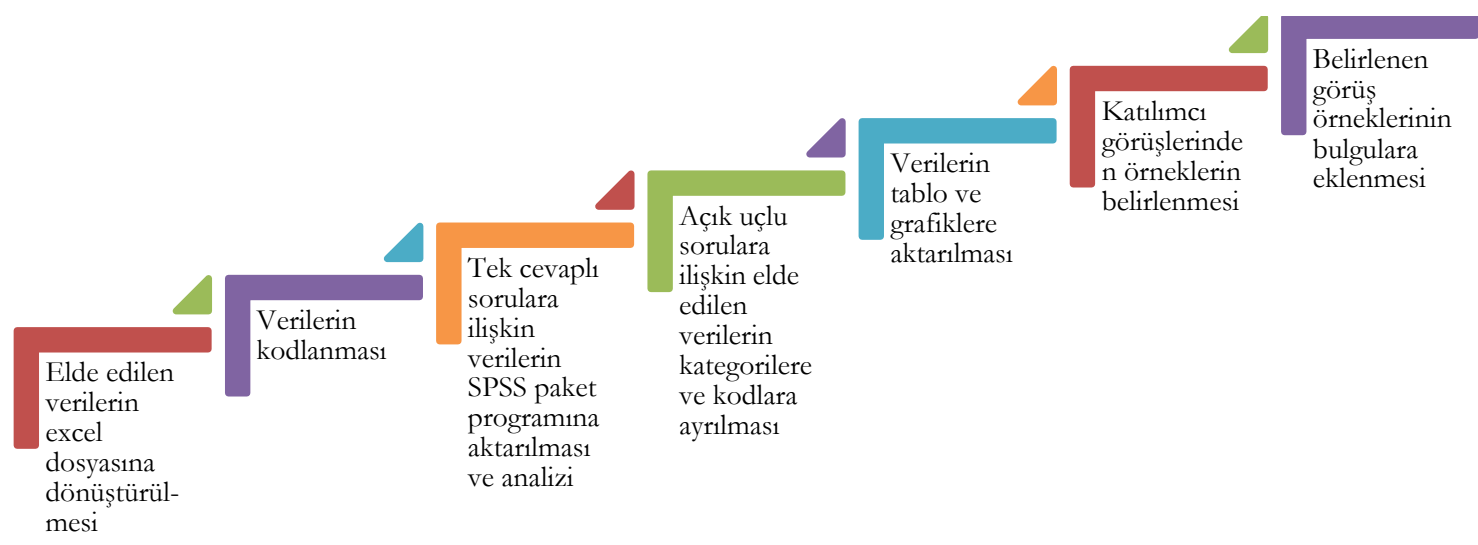

\section{Şekil 2. Veri Analizi Isslem Basamaklar}

Verilerin analizinde geçerlilik ve güvenirliği sağlamak amacıyla bir takım önlemler alınmıştır. Bu bağlamda araştırma kapsamında elde edilen verilerin kategori ve kodlara ayrilmasında uzman görüşü alınmış, görüş benzerlikleri ve farklılıkları belirlenmiştir. Bu bağlamda az sayıdaki görüş farklılıkları giderilerek analize son şekli verilmiştir. Buna ek olarak katıllmcı görüşlerine araştırmacı yorumu 
eklenmeden yer verilmiştir. Çalışma grubunda yer alan öğretmenler ise öğretmen/1, öğretmen/2 ... şeklinde kodlanmıştır.

\section{Bulgular}

Araştırma kapsamında elde edilen veriler analiz edilmiş ve birtakım bulgulara ulaşılmıştır. Öncelikle çalışma grubunda yer alan sosyal bilgiler öğretmenlerinin uzaktan eğitimde iletişimin önemine yönelik görüşleri alınmış ve katılımcıların tamamı uzaktan eğitim sürecinde iletişimin önemli olduğunu ifade etmişlerdir. Uzaktan eğitim sürecinde iletişimin neden önemli olduğuna ilişkin ileri sürdükleri gerekçeler ise Tablo 2'de yer almaktadir.

Tablo 2. Sosyal Bilgiler Öğretmenlerinin Uzaktan Eğitimde İletișimin Öneminin Gerekçelerine Yönelik Görüsleri

\begin{tabular}{lcc}
\hline Gerekçe & f & \% \\
\hline Ĕ̆itim-öğretim süreçlerinden verim elde etme & 5 & 16.6 \\
Başarı sağlama & 4 & 13.3 \\
Motivasyon arttırma & 3 & 9.9 \\
Duygu aktarımını sağlama & 3 & 9.9 \\
Ders takibini sağlama & 2 & 6.6 \\
Süreci etkin bir şekilde yönetme & 2 & 6.6 \\
Öğrenciyi takip etme & 2 & 6.6 \\
Sürece adapte etme & 2 & 6.6 \\
Öğrencilerin zamanı iyi kullanmalarını sağlama & 2 & 6.6 \\
Öğrencilerle bağın kopmaması & 2 & 6.6 \\
Velilerin problemlerini belirlemek & 2 & 6.6 \\
Öğrenci ve öğretmeni derse bağlama & 1 & 3.3 \\
Anlaşılmayan konulara açıklık getirme & 1 & 3.3 \\
\hline
\end{tabular}

Tablo 2 incelendiğinde katılımcıların uzak eğitimde en fazla eğitim-öğretim sürecinde verim elde etmek ( $f=5, \% 16.6$ ) için iletişimin önemli olduğu görüşüne sahip oldukları görülmektedir. Buna ek olarak sosyal bilgiler öğretmenleri uzak eğitim süresinde başarı sağlama ( $f=4, \% 13.3)$, motivasyonu arttırma $(f=3$, \%9.9), duygu aktarımını sağlama ( $\mathrm{f}=3, \% 9.9)$ gibi gerekçeler göstererek iletişimin önemli olduğu görüşünü ileri sürmüşlerdir. Sosyal bilgiler öğretmenlerinin uzaktan eğitim sürecinde iletişimin neden önemli olduğuna ilişkin görüşleri genel olarak incelendiğinde ise daha çok iletişimin öğrenci açısından önemine odaklandıkları söylenebilir. Aşağıda öğretmenlerin gerekçelerinden bazı örneklere yer verilmiştir:

"Önemlidir. Öğrenci ile iletişim kurmak yaptığımı işin en önemli tarafi. İyi bir iletişim kurmadan yapulacak isler sanki öylesine yapulyyormus gibi oluyor.” (Öğretmen/2)

"Tabi ki önemlidir. Cünkü ögrencileri motive etme açısından büyük zorluklar yaşyoruz adapte sürecini daha kolay atlatmalar için hem velilerle hem öğrencilerimizle daba çok iletişim içerisinde olmamı gerekiyor." (Öğretmen/6)

"İletişim önemlidir. İletişim yüzyüze eğitimin de en önemli unsurlarndandir. Olumlu kurulan ögretmen-ögrenci iletişimi eğitimin en önemli unsurlarındandır." (Öğretmen/15)

"Sadece uzaktan eğitimde değil her zaman iletişim gereklidir. Eğgitim işi karşılıh iletişim ile olur. İletişimin tüm türlerini(sözlü -yazıll-beden dili) eğitim sürecine kattı̆gmızda verim elde ederiz diye düş̈nüyorum." (Öğretmen/17)

"Kesinlikle önemlidir; ama sadece sǫ̈lü iletisim baẓen yeterli olmayabiliyor bilhassa ögrencilerle görüntü olarak temas etmeniz gerekiyor çocuk bazen söylediklerimiz tam anlamaya biliyor beden dili bunun tamamlayncısı olduğu için iletişim sadece bir yönden değil birçok yönden gerekli oluyor.” (Ö̈̆retmen/26)

“Önemlidir. Çünkü karşılıkl iletişimin olmadiğ yerde ĕgitim ve ögretimin etkisi çok azalmaktadır. Öğrenciler bu süreçte her ne kadar EBA TV gibi yerlerden yararlansa bile yanlıs yaptığında alacă̆ dönütün etkileşimli şekilde olması soru aklına geldiğinde sorması ve cevaplanması çok önemlidir.” (Ö̆ğretmen/28)

Araştırma kapsamında çalışma grubunda yer alan sosyal bilgiler öğretmenlerinin Covid-19 salgınında gerçekleştirdikleri uzaktan eğitim sürecinde en fazla kiminle iletişim kurduklarını ortaya çıkarmak amaçlanmış ve şekil 3’teki bulgulara ulaşılmıştır. 


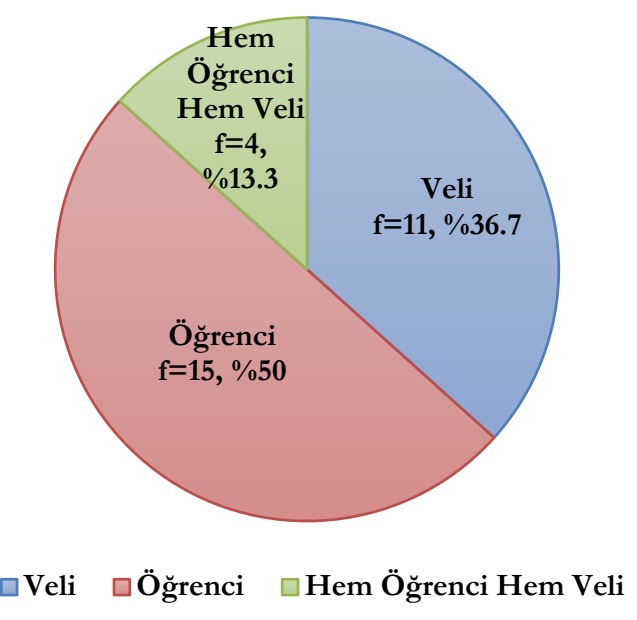

Şekil 3. Uraktan Eğitim Sürecinde En Faそla İletişim Kurulan Kitleye İlişkin Bulgular

Şekil 3 incelendiğinde çalışma grubunda yer alan sosyal bilgiler öğretmenlerinin uzaktan eğitim sürecinde en fazla öğrencileriyle $(\mathrm{f}=15, \% 50)$ iletişim kurdukları görülmektedir. Bunun dışında bazı öğretmenler bu süreçte hem öğrenci ile hem de velilerle ( $\mathrm{f}=4, \% 13.3$ ) fazla iletişim kurduklarını ifade etmişlerdir. Uzaktan eğitim sürecinde öğretmenlerin öğrencilerle daha fazla iletişim kurmasında ise eğitimöğretim faaliyetlerinde öğrencinin daha aktif rol alması etkili olabilir.

Uzaktan eğitim sürecinde hem öğrencilerle hem de veliler kurulan iletişimde kullanılan araçlara ilişkin bulgular şekil 4’te yer almaktadır.

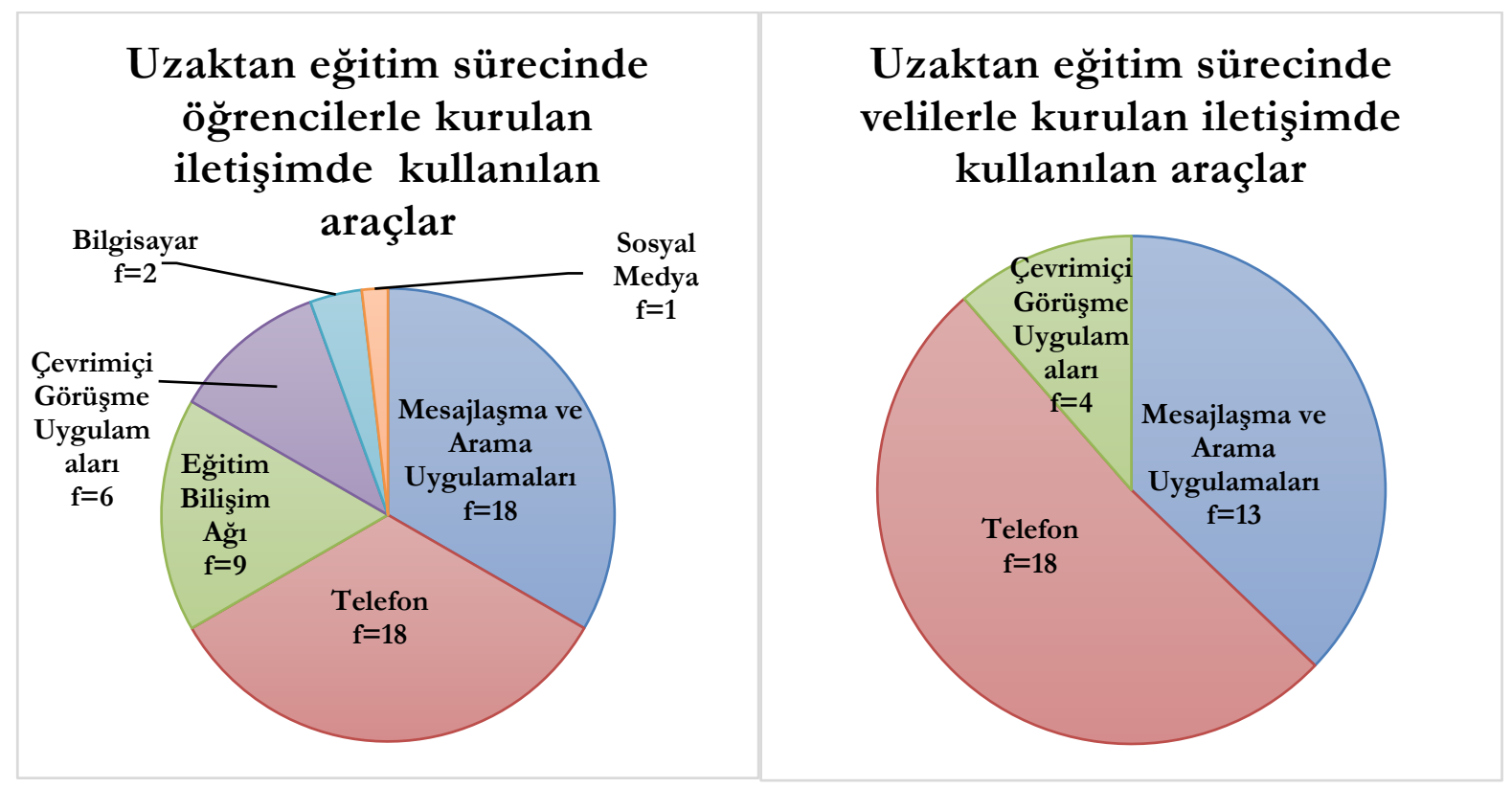

Şekil 4. Uz̧aktan Ë̆itim Sürecinde Ögrrenci ve Velilerle Kurulan İletişim Kullamlan Araçlara İlişkin Bulgular

Şekil 4 incelendiğinde sosyal bilgiler öğretmenlerinin öğrencilerle iletişim kurarken en fazla mesajlaşma ve arama uygulamaları $(\mathrm{f}=18)$ ile telefonu $(\mathrm{f}=18)$ kullandıkları görülmektedir. Buna ek olarak eğitim bilişim ağı $(\mathrm{f}=9)$, çevrimiçi görüşme uygulamaları $(\mathrm{f}=6)$, bilgisayar $(\mathrm{f}=2)$ ve sosyal medya $(\mathrm{f}=1$ ) gibi araçları da yine öğrencileriyle iletişim kurmak için kullanmışlardır. Sosyal bilgiler öğretmenleri velilerle en fazla telefon ( $\mathrm{f}=18$ ) aracilı̆̆ıly iletişim kurmuşlardır. Bunun dışında çeşitli mesajlaşma ve arama uygulamaları ( $\mathrm{f}=13$ ) ile çevrimiçi görüşme uygulamaları $(\mathrm{f}=4)$ velilerle iletişim kurmak amacıyla kullanılmıştır. Öğretmenlerin öğrencileriyle kurdukları iletişimde kullandığı iletişim araçları velilere göre daha çeşitli ve fazladır. Bu durum üzerinde ise sosyal bilgiler öğretmenlerinin uzaktan eğitim sürecinde öğrencilerle daha fazla iletişim kurmaları etkili olabilir. 
Tablo 3'te çalışma grubunda yer alan sosyal bilgiler öğretmenlerinin Covid-19 salg1nında gerçekleştirdikleri uzaktan eğitim sürecinde hem öğrenci hem de velilerle iletişim kurma gerekçelerine ilişkin bulgulara yer verilmiştir.

Tablo 3: Sosyal Bilgiler Ö̆gretmenlerinin Uzaktan Ë̆̈tim Sürecinde Öğrenci ve Velilerle İletişim Kurma Gerekçelerine Iliskin Bulgular

\begin{tabular}{|c|c|c|c|}
\hline Kitle & İletişim Kurma Gerekçesi & $\mathrm{f}$ & $\%$ \\
\hline \multirow{12}{*}{ Öğgrenci } & Ders verme & 7 & 23.3 \\
\hline & Motive etme & 6 & 19.9 \\
\hline & Ödev verme & 5 & 16.6 \\
\hline & Katılım sağlama & 5 & 16.6 \\
\hline & Bilgilendirme & 4 & 13.3 \\
\hline & Yönlendirme & 3 & 9.9 \\
\hline & Rehberlik etme & 2 & 6.6 \\
\hline & Test çözümü & 1 & 3.3 \\
\hline & Sinava hazırlama & 1 & 3.3 \\
\hline & Özlem giderme & 1 & 3.3 \\
\hline & Ders takibi & 1 & 3.3 \\
\hline & Başarıyı arttırma & 1 & 3.3 \\
\hline \multirow{10}{*}{ Veli } & Öğrenciyi kontrol etme & 5 & 16.6 \\
\hline & Motive etme & 4 & 13.3 \\
\hline & Süreç hakkında bilgi verme & 4 & 13.3 \\
\hline & Durum bilgisi paylaşma & 3 & 9.9 \\
\hline & Ödev kontrolü yapmalarını sağlama & 2 & 6.6 \\
\hline & Sürece dahil etme & 1 & 3.3 \\
\hline & Destek olma & 1 & 3.3 \\
\hline & Süreçteki olumsuzlukları engelleme & 1 & 3.3 \\
\hline & Derse ilgiyi arttırma & 1 & 3.3 \\
\hline & Öğrenci başarısını arttırma & 1 & 3.3 \\
\hline
\end{tabular}

Tablo 3 incelendiğinde uzaktan eğitim sürecinde sosyal bilgiler öğretmenlerinin öğrencileriyle daha çok ders verme ( $f=7, \% 23.3)$, motive etme ( $f=6, \% 19.9)$, ödev verme ( $f=5, \% 16.6)$, katılım sağlama $(f=5$, \%16.6), bilgilendirme ( $\mathrm{f}=4, \% 13.3)$, yönlendirme $(\mathrm{f}=3, \% 9.9)$ gibi gerekçelerle iletişim kurdukları görülmektedir. Sosyal bilgiler öğretmenleri uzaktan eğitim sürecinde velilerle öğrenciyi kontrol etme ( $f=5$, \%16.6), veliyi motive etme ( $\mathrm{f}=4, \% 13.3$ ), süreç hakkında bilgi verme ( $\mathrm{f}=4, \% 13.3)$, durum bilgisi paylaşma ( $f=3, \% 9.9)$ gibi gerekçelerle iletişim kurmuşlardır. Uzaktan eğitim sürecinde sosyal bilgiler öğretmenlerinin öğrencilerle iletişim kurma gerekçeleri velilerle iletişim kurma gerekçelerine göre daha çeşitli olmuştur. Öğretmenlerin hem öğrenciler hem de velilerle ortak olarak ileri sürdüğü iletişim kurma gerekçesi ise motive etmedir. Katılımcı görüşleri genel olarak ele alındığında uzak eğitim sürecini daha etkin bir şekilde ilerlemesi için de hem öğrenci hem de velilerle iletişim kurdukları görülmektedir.

Uzaktan eğitim sürecinde hem öğrenciler hem de velilerle iletişim kurarken herhangi bir sorunun yaşanıp yaşanmadığına ilişkin bulgulara şekil 5'te yer verilmiştir. 


\section{Uzaktan eğitim sürecinde öğrencilerle iletişim kurarken;}

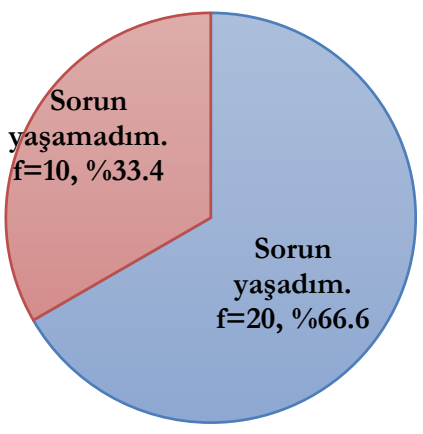

$\square$ Sorun yaşadım. $\square$ Sorun yaşamadım.

\section{Uzaktan eğitim sürecinde velilerle iletişim kurarken;}

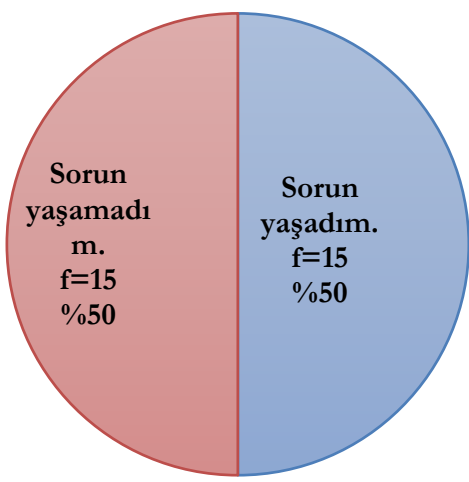

$\square$ Sorun yaşadım. $\square$ Sorun yaşamadım.

Şekil 5. Uzaktan Eğitim Sürecinde Ögrenci ve Velilerle Kurulan İletişimde Sorun Yaşama Durumuna İliskin Bulgular

Şekil 5 incelendiğinde çalışma grubunda yer alan sosyal bilgiler öğretmenlerinin çoğunun ( $\mathrm{f}=20$, \%66.6) Covid-19 salgını sürecinde gerçekleştirilen uzaktan eğitim faaliyetleri sırasında öğrencileriyle iletişim kurarken sorun yaşadığı görülmektedir. Buna ek olarak katılımcıların yarısı $(\mathrm{f}=15, \% 50)$ velilerle uzaktan eğitim sürecinde iletişimsel sorunlar yaşamıştır. Uzaktan eğitim sürecinde öğretmenler daha fazla öğrencilerle iletişimsel sorunlar yaşamışlardır. Bu durum ise öğretmenlerin öğrencilerle daha fazla iletişim kurması, velilerin iletişim becerilerinin yaşlarına bağlı olarak daha gelişmiş olmasının velilerle daha az iletişim sorunu yaşanmasına olanak tanıdığı şeklinde yorumlanabilir.

Çalışma grubunda yer alan sosyal bilgiler öğretmenlerinin uzaktan eğitimde hem öğrencileriyle hem de velileriyle gerçekleştirdikleri iletişim süreçlerinde yaşadıkları sorunlar ayrıntılı bir şekilde incelenmiştir. Tablo 4'te uzaktan eğitim sürecinde katılımcıların öğrencileriyle yaşadıkları iletişim sorunlarına yönelik görüşlerine yer verilmiştir.

Tablo 4. Uzaktan Eğitim Sürecinde Sosyal Bilgiler Ögrretmenlerinin Öğrencileriyle Gerçekleşsirdiği İletişim Süreģlerinde Yaşadıklar Sorunlar

\begin{tabular}{|c|c|c|c|}
\hline Kategoriler & Kodlar & f & $\%$ \\
\hline \multirow{2}{*}{ Veli kaynaklı sorunlar } & Teknoloji okuryazarlı̆̆ının gelişmemiş olması & 2 & 6.6 \\
\hline & Velilerin öğrencileri kısıtlaması & 1 & 3.3 \\
\hline \multirow{4}{*}{$\begin{array}{l}\text { Olanak eksikliğinde kaynaklı } \\
\text { sorunlar }\end{array}$} & İletişim araçlarının eksikliği & 4 & 13.3 \\
\hline & İnternetin olmamas1 & 4 & 13.3 \\
\hline & Şebekenin çekmemesi & 3 & 9.9 \\
\hline & İmkânların kısıtlı olması & 2 & 6.6 \\
\hline \multirow{2}{*}{ Öğrenci kaynaklı sorunlar } & Öğrencinin çekingen olması & 2 & 6.6 \\
\hline & Öğrencilerin durumun ciddiyetini kavrayamaması & 1 & 3.3 \\
\hline \multirow{3}{*}{$\begin{array}{l}\text { İletişim sürecindeki } \\
\text { eksikliklerden kaynaklanan } \\
\text { sorunlar }\end{array}$} & Göz teması kuramama & 3 & 9.9 \\
\hline & Sesleri duyamama & 2 & 6.6 \\
\hline & Duygu paylaşımının olmaması & 2 & 6.6 \\
\hline
\end{tabular}

Tablo 4 incelendiğinde çalışma grubunda yer alan sosyal bilgiler öğretmenlerinin veli kaynaklı daha çok velilerin teknoloji okuryazarlıklarının gelişmemiş olması ( $\mathrm{f}=2, \% 6.6)$, olanak eksikliğinde kaynaklı iletişim araçlarının eksikliği $(\mathrm{f}=4, \% 13.3)$ ve internetin olmaması ( $\mathrm{f}=4, \% 13.3)$, öğrenci kaynaklı olarak öğrencilerin süreçte çekingen davranması $(\mathrm{f}=2, \% 6.6)$ ve iletişim sürecindeki eksikliklerden kaynaklı göz temasının kurulamamasından $(\mathrm{f}=3, \% 9.9)$ dolayı öğrencileriyle iletişim kurmakta sorunlar yaşadıkları görülmektedir. Öğretmen görüşlerinden yola çıkarak oluşturulan kategoriler incelendiğinde ise uzaktan eğitim sürecinde öğretmen-öğrenci iletişimi veli, olanak eksikliği, öğrenci ve iletişim sürecindeki eksikliklerde kaynaklı bir takım sorunların yaşamasına sebep olmuştur. Aşağıda sosyal bilgiler 
öğretmenlerinin uzaktan eğitim sürecinde öğrencileriyle yaşadıkları iletişimsel sorunlara yönelik görüşlerinden bazı kesitlere yer verilmiştir:

"Öğrencilerin tamam ile iletişim kurmak oldukça zor zaten. Pandemi dolayısı ile evlerinden çı-mak istemeyen aileler olmasından kaynaklı biz. de daba çok telefon ile iletişim kurmay uygun gördük." (Öğretmen/3)

"Öğrencilerin konusurken çekingen olmalar, bulunduklar yerde internet olmamasi ya da sebekenin çekmemesi.” (Öğretmen/8)

"Sadece 4-5 ögrenci ile iletişimimiz cok kuvvetli oldu. Onun dişında ögrencilerin elinde yeterli iletişim araçlar olmadı̆̆ için sık.ıntı yaşadık.” (Öğretmen/26)

Tablo 5'te sosyal bilgiler öğretmenlerinin uzaktan eğitim sürecinde velilerle gerçekleştirdikleri iletişim süreçlerinde yaşadıkları sorunlara ilişkin görüşlerine yer verilmiştir.

Tablo 5. Uzaktan Eğitim Sürecinde Sosyal Bilgiler Öğretmenlerinin Velilerle Gerçekleştirdiği İletişim Süreçlerinde Yasadiklar Sorunlar

\begin{tabular}{|c|c|c|c|}
\hline Kategoriler & Kodlar & f & $\%$ \\
\hline \multirow{5}{*}{ Veli kaynaklı sorunlar } & Velilerin öğrencileri motive etmemesi & 4 & 13.3 \\
\hline & Velilerin iş yoğunluğu & 4 & 13.3 \\
\hline & Velilerin öğretmene karşı sergilediği olumsuz tavır & 3 & 9.9 \\
\hline & İletişim bilgilerinin yanlış olması & 3 & 9.9 \\
\hline & Uzaktan eğitimin önemsenmemesi & 1 & 3.3 \\
\hline \multirow{2}{*}{$\begin{array}{l}\text { Olanak eksikliğinde } \\
\text { kaynaklı sorunlar }\end{array}$} & İnternetin olmamas1 & 4 & 13.3 \\
\hline & İmkânların k1sıtlı olması & 2 & 6.6 \\
\hline
\end{tabular}

Tablo 5 incelendiğinde çalışma grubunda yer alan sosyal bilgiler öğretmenlerinin uzaktan eğitim sürecinde veli kaynaklı olarak velilerin öğrencileri motive etmemesi ( $\mathrm{f}=4, \% 13.3$ ), velilerin iş yoğunluğu $(\mathrm{f}=4, \% 13.3)$, velilerin öğretmene karş1 sergiledikleri olumsuz tavir $(\mathrm{f}=3, \% 9.9)$, velilere ait iletişim bilgilerindeki eksik veya yanlışlıklar ( $\mathrm{f}=3, \% 9.9)$ ve velilerin uzaktan eğitim sürecini önemsememesinden $(\mathrm{f}=1, \% 3.3)$ dolay1 iletişimsel sorunların yaşandığ1 görünmektedir. Buna ek olarak çalışma grubunda yer alan öğretmenlerin internet eksikliği ( $\mathrm{f}=4, \% 13.3)$ ve imkanların k1sitlı olması (f=2, \%6.6) gibi olanak eksikliğinden kaynaklı da bazı iletişimsel sorunlanı ifade etmişlerdir. Aşağıda uzaktan eğitim sürecinde velilerle iletişim kurarken yaşanan problemlere yönelik öğretmen görüş örneklerine yer verilmiştir:

"Bą̧ veliler iş koşullarından dolayı çocuklarmm yanında değiller, bu yüzden kopukluklar yaşandı."

(Öğretmen/6)

"Ögrrencilerin canl derslere aktif katılım konusunda velinin yeterli imkân ve desteği sağlayamaması sorun teşkil etti." (Ö̈̆retmen/27)

"Veliler başlangıçta uzaktan eğitimi önemsemediği için katılım konusunda gerekli desteği vermediler." (Öğretmen/28)

Son olarak uzaktan eğitim sürecinde iletişim süreçlerine yönelik çalışma grubunda yer alan sosyal bilgiler öğretmenlerinin görüşleri alınmış ve Tablo 6'daki bulgulara ulaşılmıştır.

Tablo 6. Uzaktan Eğitimde İletişim Süreclerine Yönelik Öneriler

\begin{tabular}{lcc}
\hline Kodlar & $\mathbf{f}$ & $\%$ \\
\hline Alt yapı sorunları giderilmeli & 6 & 19.9 \\
İletişim sürekli olmalı & 5 & 16.6 \\
İletş̧im öğrenciyi motive edecek ş̧ekilde planlanmalı & 13.3 \\
İletşim yüz yüze olmalı & 4 & 9.9 \\
İletişim düzenli olarak gerçekleştirilmeli & 3 & 6.6 \\
İletişim şeffaf olmalı & 2 \\
Planlı iletişim süreçleri tasarlanmalı & 2 & 6.6 \\
İletişim süreçlerinin ciddiyeti kavranmalı & 2 & 6.6 \\
İletşsim süreçleri öğretmen-öğrenci etkileşimine olanak tanımalı & 2 & 6.6 \\
İletişim süreçlerinin ciddiyeti kavranmalı & 2 & 6.6 \\
Dönütler etkili bir şekilde yapılmalı & 1 & 3.3 \\
Öğrenci veya veli kaynaklı iletişim problemleri çözülmeli & 1 & 3.3 \\
İletişim süreci eğlenceli hale getirilmeli & 1 & 3.3 \\
\hline
\end{tabular}


Tablo 6'da çalışma grubunda yer alan sosyal bilgiler öğretmenlerinin uzaktan eğitim sürecinde iletişim sorunlarının ortadan kalkması ve etkili bir iletişim sürecinin geliştirilmesine yönelik alt yapı sorunlarının giderilmesi ( $\mathrm{f}=6, \% 19.9)$, iletişimin sürekli olması $(\mathrm{f}=5, \% 16.6)$, iletişimin öğrenciyi motive edecek şekilde olması ( $\mathrm{f}=4, \% 13.3)$, iletişimin yüz yüze olması ( $\mathrm{f}=3, \% 9.9)$, iletişimin düzenli olarak gerçekleştirilmesi $(\mathrm{f}=2, \% 6.6)$, şeffaf olması ( $\mathrm{f}=2, \% 6.6)$, planlı olması ( $\mathrm{f}=2, \% 6.6)$, ciddiyetin kavranması $(\mathrm{f}=2, \% 6.6)$ ve iletişim süreçlerinin öğretmen-öğrenci etkileşimine olanak tanıması ( $\mathrm{f}=2, \% 6.6)$ gibi önerileri ileri sürdükleri görülmektedir. Aşağıda uzaktan eğitimde iletişim süreçlerine yönelik geliştirilen önerilerden örneklere yer verilmiştir:
"Tüm ögrencilere aym anda ulașabileceğimiz bir kanal olmah mutlaka düzenli planl programli yapılmah. Ë̆gr bu şekilde olmąsa sadece öylesine yapılyyormus gibi oluyor.” (Öğretmen/2)
"Sürekli iletişim içerisinde olmamı gerekiyor. Bu süreçte veli öğrenci okul işbirliği zayıf kalyyor daba çok video konferans yöntemiyle bir araya gelmek, gerekiyor." (Öğretmen/6)
"Ögrencilerin motive edilmesine yönelike olmal. Öğrenciyle iletişim kurunca kendisinin önemli olduğunu hissetmesi gerekiyor." (Öğretmen/11)

\section{Tartışma, Sonuç ve Öneriler}

Araştırma kapsamında elde edilen bulgular doğrultusunda bir takım sonuçlara ulaşılmıştır. Araştırma sonuçları ise ilgili literatür incelenerek benzer çalışma sonuçlarıly karşılaştırılarak tartışılmıştır. Etkin ve kalıcı bir öğrenmenin ön koşulu etkili bir şekilde kurulan iletişimdir (Aydın, 2019, s. 180). Bu yüzden iletişim eğitim-öğretim faaliyetlerinde önemlidir. Araştırma kapsamında yer alan katılımcıların tamamı da uzaktan eğitim sürecinde iletişimin önemli olduğu görüşünü ileri sürmüşlerdir. Bu duruma gerekçe olarak da genel olarak uzaktan eğitim faaliyetlerinin amacına ulaşmasını göstermişlerdir. Başka bir ifadeyle çalışma grubunda yer alan sosyal bilgiler öğretmenleri salgin sürecinde uzaktan eğitimde amaca ulaşmak, süreci etkin bir şekilde sürdürmek için iletişimin önemli olduğu fikrini ileri sürmüşlerdir.

Covid-19 salgını sürecinde gerçekleştirilen uzaktan eğitim faaliyetlerinde az veya çok birçok öğretmen öğrenci, veli, idare gibi farklı hedef kitlelerle iletişim kurma zorunluluğu veya gerekliliği duymuştur. $\mathrm{Bu}$ süreçte hedef kitleyle iletişim kurma sıklığı birbirinden farklılık gösterebilir. Çalışma sonucunda ise sosyal bilgiler öğretmenlerinin uzaktan eğitim sürecinde daha çok ögrencileriyle iletişim kurduklarına ulaşılmıştır. Bunun nedenleri arasında ise eğitim-öğretim faaliyetlerinde daha çok öğrenci ve öğretmenin rol alıyor olması gösterilebilir.

Araştırma kapsamında sosyal bilgiler öğretmenlerinin hem öğrenciler hem de velilerle iletişim kurarken hangi araçları kullandıkları incelenmiştir. İnceleme sonucunda sosyal bilgiler öğretmenlerinin hem öğrencileriyle hem de velileriyle daha çok telefon ile mesajlaşma ve arama uygulamaları kullanarak iletişim kurdukları sonucuna ulaşılmıştır. Buna ek olarak sosyal bilgiler öğretmenleri öğrencileriyle velilere göre daha fazla çeşitte iletişim aracı kullanarak iletişim kurmuşlardır.

Çalışma grubunda yer alan sosyal bilgiler öğretmenlerinin öğrenci ve velileriyle kurdukları iletişimin gerekçeleri ayrı ayrı ele alınmıştır. Buna göre sosyal bilgiler öğretmenleri öğrencileriyle daha çok ders verme, motive etme, ödev verme ve katılım sağlama gibi süreci etkin şekilde yönetmeye yönelik amaçlarla; velileriyle de öğrenciyi kontrol etme, motive etme ve süreç hakkında bilgi verme gibi amaçlarla iletişim kurduklarını ileri sürmüşlerdir. Sosyal bilgiler öğretmenlerinin hem öğrenci hem de velilerle iletişim kurma gerekçelerinde motive etmenin ortak olarak yer alması ise salgın sürecinin olumsuz psikolojik etkilerinden kaynaklı olabilir. Çünkü, uzaktan eğitimde etkileşim bir motivasyon unsuru olarak ele alınabilir (Deveci, 2019). Bu yüzden uzaktan eğitimde etkileşim sağlamak için başvurulan iletişim yollannda da hedef kitleyi motive etmenin önemli bir gereklilik olduğu söylenebilir.

İletişim süreçleri her zaman planlandığı veya beklendiği gibi olmayabilir. Gönderici ve alıcı arasındaki hiyerarşik, psikolojik, dil ve teknik farklılıklar iletişim süreçlerinde bazı engel veya sorunların oluşmasında etkili olabilir (Yılmazer, 2020, s. 69). Eğitim-öğretim ortamlarında iletişimi zedeleyen veya zorlaştıran birçok etken bulunmaktadır. Sürecin doğasına bağlı olarak da iletişimde yaşanabilecek sorunlar birden fazla ögeyle açıklanabilir. İletişim sürecinde sorunlar kaynak, alıcı veya iletiyle ilgili olabilir (Gökdağ, 2019, s. 108). Uzaktan eğitim sürecinde de bir takım iletişim engelleri yaşanmaktadır. Uzaktan eğitim sürecinde iki yönlü iletişsimin olmaması ve eğitmene erişim eksikliği süreçte yaşanabilecek çeşitli zorluklara yol açabilir (Berge, 2013, s. 377). Uzaktan eğitim sürecinde teknik alt yap1, bilgisayar, internet ve yazılımlara erişim gibi sorunlar yaşanabilir (Özcan, 2020, s. 202-203). Bu çalışmadan elde edilen bulgular doğrultusunda da 
uzaktan eğitim sürecinde öğretmenlerin hem öğrenci hem de velilerle bir takım iletişim sorunları yaşadıkları sonucuna ulaşılmıştır. Bu süreçte sosyal bilgiler öğretmenleri öğrencileriyle daha fazla sorun yaşadıklarını ileri sürmüşlerdir. Öğrencilerle gerçekleştirilen iletişim sürecinde veli, olanak eksikliği, öğrencinin kendisi ve iletissim sürecindeki eksikliklerden kaynaklı sorunlar yaşanmıştır. Sosyal bilgiler öğretmenlerinin ileri sürdükleri sorunlar ayrıntılı olarak incelendiğinde ise iletişim araçlarının eksikliği, internetin olmaması, şebekenin çekmemesi, duygu paylaşımının olmaması, öğrencilerin durumun ciddiyetini kavrayamaması ve süreçte çekingen davranmaları gibi sorunlar olduğu görülmektedir. Benzer şekilde Akca (2006) da çalış̧ması sonucunda uzaktan eğitim öğrencilerinin teknik, psikolojik, kişisel, kesinti, zaman baskısı gibi bir takım iletişim engelleri yaşadıklarına ulaşmışlardır. Elcil ve Sözen-Şahiner (2014) de çalışmaları sonucunda iletişim fakültesi öğrencilerinin uzaktan eğitim sürecinde motive eksikliği, geri bildirim eksikliği ve zaman baskısı gibi iletişim sorunları yaşadıklarına ulaşmışlardır. Bayburtlu (2020) Türkçe öğretmenlerinin uzaktan eğitim sürecinde öğrencilerin internet erişiminin olmayışı, bağlantı ve zaman sorunları yaşadıkları sonucuna ulaşmıştır. Canpolat ve Yıldırım (2021) da öğretmenlerin uzaktan eğitim sürecinde öğretmen, öğrenci, erişim ve alt yapı, canlı ders ortamı ve yönetim kaynaklı bir takım problemler yaşadıklarına ulaşmışlardır. Son olarak, Bakioğlu ve Çevik (2020) Fen bilimleri öğretmenlerine yönelik gerçekleştirdikleri çalışmaları sonucunda katılımcıların uzaktan eğitim sürecinde iletişim kopukluğu, iletişim zayıflığı ve motivasyon düşüklüğü gibi sorunlar yaşadıklarına ulaşmışlardır. Bu bağlamda benzer çalışma bulgularının bu çalışmadan elde edilen sonuçları destekler nitelikte olduğu söylenebilir.

Çalışma grubunda yer alan sosyal bilgiler öğretmenlerinin velilerle gerçekleştirdikleri iletişim süreçlerinde ise daha çok veli kaynaklı bir takım sorunlar (velilerin öğrencileri motive etmemesi, iş yoğunlukları...) yaşadıkları sonucuna ulaşılmıştır. Son olarak uzaktan eğitim faaliyetleri sırasında iletişim süreçlerinin nasıl olması gerektiğine yönelik sosyal bilgiler öğretmeni önerileri ele alınmıştır. Öneriler incelendiğinde ise sosyal bilgiler öğretmenlerinin uzaktan eğitim sürecindeki iletişimin gerçekleştirilmesine yönelik alt yapı sorunlarının giderilmesi, iletişimin sürekli, sürekli ve planlı olması, ciddiyete alınması, eğlenceli hale getirilmesi gibi görüşler ileri sürdüklerine ulaşılmıştır.

Araştırma sonucunda uzaktan eğitim süreçlerinde öğretmen-öğrenci ve öğretmen-veli iletişim sürecinde bir takım sorunların yaşandığına ulaşılmıştır. Bu sorunlar daha ayrıntılı bir şekilde incelenip çözüm önerileri geliştirilebilir. Uzaktan eğitim sürecinin daha etkin bir şekilde devam etmesi için sürecin paydaşlarına (öğretmen, öğrenci ve veli) iletişim seminerleri veya bilgilendirme içerikleri planlanabilir. Uzaktan eğitim sürecinde en fazla yaşanan sorunlardan biri de erişim sorunudur. Bu bağlamda öğrenci, veli ve öğretmenlerin birbirlerine erişim sorunlarının nedenleri tespit edilerek giderilmeye yönelik önlemler alınabilir. Özellikle dönem başlarında veya dönem içinde ara ara velilerle toplantılar yapılarak, öğretmenler tarafından daha önceden belirlenen iletişim kuralları velilerle paylaşılabilir.

\section{Etik Beyan}

"Uzaktan Ë̆gitim Sürecinde Öğretmen ile Öğrenci-Veli İletişimi: Sosyal Bilgiler Öğretmenlerinin Deneyimleri” başliklı çalışmanın yazım sürecinde bilimsel kurallara, etik ve alıntı kurallarına uyulmuş; toplanan veriler üzerinde herhangi bir tahrifat yapılmamış ve bu çalışma herhangi başka bir akademik yayın ortamına değerlendirme için gönderilmemiştir. Gerekli olan etik kurul izinleri Artvin Çoruh Üniversitesi Bilimsel Araştırma ve Yayın Etiği Kurulu’nun 26.08.2020 tarih ve 2020/11 sayllı toplantısında alınmıştır.

\section{Kaynakça}

Akca, Ö. (2006). SAÜ uحaktan eğitim ögrrencilerinin iletişim engelleri ile ilgili ögrenci görüsleri (Yüksek Lisans Tezi). Sakarya Üniversitesi Sosyal Bilimler Enstitüsü, Sakarya.

Aydın, A. (2019). Sinffyönetimi (20. Baskı). Ankara: Pegem Akademi.

Bayburtlu, Y. S. (2020). Covid-19 pandemi dönemi uzaktan eğitim sürecinde öğretmen görüşlerine göre Türkçe eğitimi. Turkish Studies, 15(4), 131-151.

Bakioğlu, B. ve Çevik, M. (2020). COVID-19 pandemisi sürecinde fen bilimleri öğretmenlerinin uzaktan eğitime ilişkin görüşleri. Turkish Studies, 15(4), 109-129.

Berge, Z. L. (2013). Barriers to communication in distance education. Turkish Online Journal of Distance Education, 14(1), 374-388.

Berigel, M. ve Çetin, İ. (2020). Açık ve uzaktan öğretimde öğreten ve öğrenen rolleri. İçinde E. Tekinarslan ve M. D. Gürer (Eds.). Açı ve uzaktan ögrenme (3. Baskı) (ss. 127-145). Ankara: Pegem Akademi.

Canpolat, U. ve Yildırım, Y. (2021). Ortaokul öğretmenlerinin COVID-19 salgin sürecinde uzaktan eğitim deneyimlerinin incelenmesi. Açıkögretim Uygulamalar ve Arastırmalar Dergisi (AUAd),7(1), 74-109.

Deveci, M. (2019). Türkiye'de yeni iletişim teknolojilerinin yüksekëğrenim kurumlarnda uz̧aktan eğitim alanında kullanım (Doktora Tezi). Marmara Üniversitesi Sosyal Bilimler Enstitüsü, İstanbul. 
Devran, Y. ve Elitaş, T. (2017). Yeni iletişim teknolojilerinin uzaktan eğitime entegrasyonu sürecinde sanal sınıf ortamlar1: Atauzem Örneği. MANAS Sosyal Araștırmalar Dergisi, 6(2), 213-225.

Durdu, L. (2020). Açık ve uzaktan öğrenmede sorunlar ve çözüm önerileri. E. Tekinarslan ve M. D. Gürer (Eds.). Açı ve uzaktan ögrenme (3. Baskı) (ss. 227-268). Ankara: Pegem Akademi.

Elcil, Ş. \& Sözen Şahiner, D. (2014). Uzaktan eğitimde iletişimsel engeller. Sosyal ve Beşeri Bilimler Dergisi, 6(1), 21-33.

Fidan, M. (2019). Sözsüz iletişim. İçinde M. Fidan ve B. Urhan Torun (Eds.). Konusulmayan dil sözsüz iletişim (Genişletilmiş 2. Baskı) (ss. 1-50). Ankara: Gazi Kitabevi.

Gökdağ, D. (2019). Etkili iletişimin engelleri. İçinde U. Demiray (Edt.). Etkili iletişim (9. Baskı) (ss. 108-131). Ankara: Pegem Akademi.

Guri Rosenblit, S. (2005). 'Distance education' and 'e-learning': Not the same thing. Higher Education, 49, 467-493.

Güneş, F. (2015). Eğitimde temel kavramlar ve çağdaş yönelimler. İçinde F. Güneş (Edt.). Eğitim bilimine giriş (3.baskı) içinde (ss. 1-22). Ankara: Pegem Akademi.

Güven, B. (2016). İletişim kavramı ve iletişim sürecinin temel ögeleri. İçinde B. Güven (Edt.). Etkili iletişim (2. Baskı) (ss. 1-22). Ankara: Pegem Akademi.

Hebebci, M. F., Bertiz, Y. ve Alan, S. (2020). Investigation of views of students and teachers on distance education practices during the coronavirus (COVID-19) pandemic. International Journal of Technology in Education and Science (IJTES), 4(4), 267-282.

Koçoğlu, E., Ulu Kalın, Ö., Tekdal, D. ve Yiğen, V. (2020). Covid-19 pandemi sürecinde Türkiye'deki eğitime bakış. International Social Sciences Studies Journal, 6(65), 2956-2966.

Lindner, J., Clemons, C., Thoron, A. ve Lindner, N. (2020). Remote instruction and distance education: A response to Covid-19. Advancements in Agricultural Development, 1(2), 53-64.

Moore, M. ve Kearsley, G. (2012). Distance education: a system view. Belmont: Wadsworth.

Muilenburg, L. ve Berge, Z. L. (2001). Barriers to distance education: a factor-analytic study. The American Journal of Distance Education. 15(2), 7-22.

Özcan, S. (2020). Açık ve uzaktan öğrenmede sorunlar ve çözüm önerileri. İçinde S. Karataş ve E. Kılıç Çakmak (Edt.). Açı ve uzaktan ögrenme (ss. 195-212). Ankara: Pegem Akademi.

Redfern, S. ve Naughton, N. (2002). Collaborative virtual environments to support communication and community in internet-based distance education. Journal of Information Technology Education, 1(3), 210-220.

Schlosser, C. A. ve Anderson, M. L. (1994). Distance education: Review of the literature. Ames, IA: Iowa Distance Education Alliance.

Sönmez, V. ve Alacapınar, F. G. (2019). Örneklendirilmiş bilimsel araștırma yöntemleri (7. Bask1). Ankara: Anı Yayıncılık.

Sönmez, M., Yıldırım, K. ve Çetinkaya, F. Ç. (2020). Yeni tip Koronavirüs (SARS-CoV2) salgınına bağlı uzaktan eğitim sürecinin sınıf öğretmenlerinin görüşleriyle değerlendirilmesi. Turkish Studies, 15(6), 855-875.

Tuna, Y. (2014). İletişim kavramı ve iletişim süreci. İçinde İ. Vural (Edt.). İletişim (2. Baskı) (ss. 1-26). Ankara: Pegem Akademi.

Ulu Kalın, Ö. ve Baydar, A. (2020). Sosyal bilimlerde uzaktan eğitimin dünya ve Türkiye'deki örnek uygulamalar açısından analizi. İçinde E. Koçoğlu (Edt.). Sosyal bilimlere uz̧aktan eğitimde bakışs (ss. 263-313). Ankara: Pegem Akademi.

Usun, S. (2004). Factors affecting the application of information and communication technologies (ICT) in distance education (a case study of Turkey). Turkish Online Journal of Distance Education, 5(1), 1-16.

Yavuz, M. (2018). Eğitim ile ilgili temel kavramlar. İçinde M. Yavuz (Edt.). Eğitim bilimine giriş (ss. 1-26). Ankara: Anı.

Yılmaz, S. ve Sarpkaya, R. (2019). Eğitimin temel kavramları. İçinde A. Tanrı̈ŏğen ve R. Sarpkaya (Eds.). Ĕgitim bilimine giris (8. Baski) (ss. 1-38). Ankara: An1.

Yılmazer, A. (2020). Görsel boyutlaryla kurumsa iletişim ve stratejik iletişim yönetimi (kavram-uygulama-örnekler-öneriler). Ankara: Seçkin Yayıncılık.

Yüksel, H. (2019). İletişimin tanımı ve temel bileşenleri. İçinde U. Demiray (Edt.). Etkili iletişim (9. Baskı) (ss. 2-45). Ankara: Pegem Akademi.

\section{EXPENDAD ABSTRACT}

Events that occur in the world and affect society significantly also affect educational activities. The COVID-19 pandemic is one of the most serious events affecting the world globally in recent years. The pandemic influencing the world has also caused a number of transformations in educational activities, thereby making distance education a crucial part of education.

Education, which begins with the birth of humans and evolves rapidly, is an interdisciplinary concept (Güneş, 2015, p. 2). Education, a dynamic phenomenon, is an area of science and life (Yılmaz \& Sarpkaya, 2019 , p. 3). Educational activities may change over time depending on prevalent circumstances. Distance education is one of the processes adopted in the fulfilment of education. The use of computers and the Internet has contributed to the development and use of distance education. Traditional media such as television, printed materials, letters, and radio have been replaced by information technologies (Berigel \& 
Çetin, 2020, p. 128). Developing technologies, on the other hand, may cause several changes in both the quality and quantity of tools used in distance education.

This study used a phenomenological research design. Informed by the philosophy of Edmund Husserl, phenomenology is a research approach to explaining or studying situations, events, experiences, or concepts (Sönmez \& Alacapınar, 2019, pp. 92-93). This study examined social studies teachers' experiences in communicating with students and parents in distance education. The sampled consisted of 30 social studies teachers working in various schools in Turkey during the 2019-2020 and 2020-2021 academic year. The sample was selected through purposive sampling. The data were collected using an interview form. The interview questions were reviewed by a subject matter expert and social studies teacher prior to the application. The data collection instrument was given its final form based on feedback. The instrument consisted of 5 open-ended and 5 single-answer questions. The interview questions were sent in writing to the participants online because the data were collected during the pandemic and the participants were from different cities. The participants provided their answers in writing.

The data were analysed using content analysis. The data were examined thoroughly and sorted into categories and codes. Statistical analysis was performed through SPSS software version 22 and percentages and frequencies were computed.

The study drew some conclusions based on the findings. The findings were discussed in line with the literature and compared to those of similar previous studies. Accordingly, all participants held the view that communication is important in distance learning. As a justification for this, they also suggested that distance learning activities, in general, achieve their goal. In other words, the social studies teachers indicated that communication is crucial to achieve the goal of distance education and effectively maintain the process during the pandemic.

In distance education activities carried out during the COVID-19 pandemic, many teachers, more or less, felt the obligation or necessity to communicate with different target groups such as students, parents, and school administrators. The frequency of communicating with the target audience may vary. The study found that the social studies teachers communicate more with their students in the distance learning process. This result might be due to the fact that educational activities take place between the teacher and students.

The study also explored what tools the social studies teachers use when communicating with both students and parents. The analysis results showed that the social studies teachers communicate with both students and parents mostly by phone using messaging and calling applications. Additionally, the social studies teachers were communicating with students using more diverse communication tools compared to their communication with parents.

The reasons for social studies teachers' communication with students and parents were discussed separately. Accordingly, the social studies teachers were communicating with their students to teach, motivate, assign homework, and foster participation with the ultimate aim to effectively manage the process, while they were communicating with parents to check on students, motivate, and inform about the process. The fact that motivating was a common reason for social studies teachers' communication with both students and parents might be due to the negative psychological effects of the pandemic.

Many factors that damage or complicate communication in educational settings. Depending on the nature of the process, communication problems may also be explained by multiple elements. Communication problems may be related to the sender, receiver, or message (Gökdağ, 2019, p. 108). According to the results of the study, the social studies teachers experienced various communication problems with both students and parents in the distance education process. The social studies teachers stated that they have more problems with their students in this process. During teachers' communication with students, there were problems arising from parents, the lack of facilities, students themselves, and the deficiencies in the communication process. As for their communication with parents, the social studies teachers faced problems often caused by parents (e.g. parents' not motivating students and parents' workload).

Finally, the social studies teachers were asked for their recommendations on how communication processes should be during distance educational activities. The social studies teachers offered the following recommendations: infrastructure problems should be solved to improve communication in 
distance education, communication should be continuous and planned, it should be taken seriously, and it should be made enjoyable.

This study found that several problems are encountered in teachers' communication with students and parents in the distance education processes. These problems may be investigated in more detail to propose solutions. Communication seminars or informational content might be planned for all stakeholders of distance education to sustain the process more effectively. 